\title{
Polis Teşkilatlarında Eğitim ve İşe Alma: Karşılaştırmalı Bir Analiz*
}

\section{Training and Recruitment in Police Organizations: A Comparative Analysis}

\author{
Cemal Öztürk ${ }^{\mathrm{a}, * *}$ \\ ${ }^{a}$ Doç. Dr., Bitlis Eren Üniversitesi, İktisadi ve İdari Bilimler Fakültesi, Kamu Yönetimi Bölümü, 13100, Bitlis/Türkiye. \\ ORCID: 0000-0003-3607-1356
}

MAKALE BİLGİSI
Makale Geçmişi:
Başvuru tarihi: 13 Mayıs 2019
Düzeltme tarihi: 10 Kasım 2019
Kabul tarihi: 20 Kasım 2019
Anahtar Kelimeler:
Türk Polis Teşkilatı,
Polis Teşkilatlarında İşe Alma,
Polis Teşkilatlarında Eğitim

\section{ARTICLE INFO}

\section{Article history:}

Received 13 May 2019

Received in revised form 10 November 2018

Accepted 20 November 2018

\section{Keywords:}

Turkish National Police,

Recruitment in Police Organizations,

Training in Police Organizations.

\section{ÖZ}

Yönetim biliminin fonksiyonlarından biri de personel işlemleridir. Personel işlemleri deyince ilk adımlar işe personel alımı ve işe alımdan önce ve sonraki eğitim verilmesi süreçleridir. İç güvenlik ve polis çalışmaları açısından da ilk personel işlemi adımları işe alınma ve sonrasındaki eğitim süreçleri ve işe alma ya da istihdam iş ve işlemleridir. Bu işlemler sadece Türk Polisinde değil dünyadaki diğer polis birimlerinde de sürdürülmektedir. Buradan hareketle bu çalışmanın amacı Türk Polis Teşkilatındaki eğitim ve işe alma süreçleri ile dünyadan Amerika Birleşik Devletleri'nde Teksas Kamu Güvenliği Dairesi, Almanya'da Eyalet Adli Kolluk Teşkilat1Bundeskriminalamt ve uluslararası polis örgütlerinden İnterpol ve Europol'deki süreçlerin karşılaştırılması ve bu bağlamda benzer ve farklılıklar ile Türk Polis Teşkilatı açısından ilerleme olanağı görülen noktaların belirlenmesidir.

\section{A B S T R A C T}

One of the functions of management science is staffing. The first steps in terms of staffing are the recruitment of staff and the training before and after recruitment. From the perspective of internal security and police work, the first personnel process steps are recruitment and after-training processes and recruitment or employment jobs and transactions. These transactions are not only carried out in Turkish Police but also in other police units in the world. From this point of view, the aim of this study is to compare the training and recruitment processes in the Turkish Police Service with the processes in the world from the Texas Public Security Department in the United States, Criminal Law Enforcement-Bundeskriminalamt in Germany and Interpol and Europol, the differences and the points of possible progress in terms of the Turkish Police Organization.

\section{Giriş}

Yönetim elde kaynakların bir gaye için bir araya getirilerek o amaca varmak amacıyla beraber çalışmalarıyla oluşan süreçtir ya da bir amaca dönük olarak eldeki imkanların bir araya getirilip yönetimin fonksiyonlarının uygulandığı süreç olarak tanımlanabilir. Bazı temel fonksiyonlara sahip bu disiplinde ilk kabul gören süreçler Planlama, Örgütleme (organize etme), Personel İşleri, Yönlendirme-yönetme, Koordinasyon-eşgüdüm, Raporlama (denetleme, haberleşme) ve Bütçelemedir. Her bir fonksiyonun alt kısımlara ayrılması olağandır, bu bağlamda personel işlemleri de çok farklı alt kısımlardan meydana gelmektedir. Personel işe alma ve eğitim de bunlardan bazılarıdır.

* Bu çalışma 2015 yılında A. Faruk Mutlusu'nun danışmanlığında Dokuz Eylül Üniversitesi Sosyal Bilimler Enstitüsü Kamu Yönetimi ABD’nda kabul edilen "Türkiye'deki Adli Delil Yönetiminin Kurumsal Yapı ve İşleyişinin Uluslararası Alanla Karşılaştırmalı Analizi" adını taşıyan doktora tezinden üretilmiştir.

** Sorumlu yazar/Corresponding author. e-posta: cozturk@beu.edu.tr 
$\mathrm{Bu}$ fonksiyonların diğer yönetim alt kollarında olduğu gibi kamu yönetimi alt kollarından ve hizmetlerinden olan Güvenlik hizmetleri ya da kolunda da geçerli olduğu açıktır. Güvenliği bir çok şekil ve kıstaslarla sınıflandırabiliriz, iç ve dıș diye ikili bir ayrıma tutsak iç güvenlikte ilk akla gelenler Polis, jandarma ve sahil güvenliktir. Bunların yanında belediye zabitalarını da iç güvenlik hizmetleri anlamında burada anmak gerekir. Son dönemdeki hızlı kentleşme sürecinde Türkiye'nin kuruluş yıllarında \% 80lerde olan kırsal nüfus artık \% 10lar seviyesindedir. İç güvenlik hizmetleri açısından polislik kentlerde kendini göstermekte olup iç güvenlik ve nüfus parametreleri ele alındığında geniş olarak polis görev alanı genişliği görülmektedir.

Bir kamu hizmeti dalı olarak Polis ve iç güvenlik hizmetlerinde işe alma ve eğitim bazı farklılıklarla birlikte yönetimin temel fonksiyonlarından personel işlemlerinin alt dalı olarak yürümektedir. Türkiye Polis Teşkilatındaki eğitim ve personel işlemleri öncelikle ve geniş olarak ele alınıp mevcut durumun ortaya konması gerekmektedir. Bir defa onda işleyen süreçleri ortaya koyunca bu süreçlerin dünyadaki diğer ülke polis örgütleri ile uluslararası polis örgütlerinde uygulanan süreçlerle karşılaştırması, araştırmacılara önemli veriler sunacak ve olumlu-olumsuz çıkarımlar yapmak mümkün hale gelecektir.

$\mathrm{Bu}$ çalışmada bahse konu süreçler Türk Polis Teşkilatı ile dünyadan Amerika Birleşik Devletleri'nde Teksas Kamu Güvenliği Dairesi, Almanya'da Eyalet Adli Kolluk Teşkilatı-Bundeskriminalamt ve uluslararası polis örgütlerinden İnterpol ve Europol'deki haliyle karşılaştırılacaktır.

\section{Yönetimin ve Fonksiyonlarl, Personel İşlemlerinden İşe Alma ve Eğitim}

Yönetimin bazı tanımları şu şekildedir: belli bir grup insanın bir amaç için birlikte çalışmasında ortaya çıkan süreçtir (Güney, 2000: 261); Amaca etkili ve verimli şekilde ulaşmak için bir araya gelmiş insan grubu arasında işbirliği ve koordinasyon sağlamaya dair yapılan çalışmaların tamamı (Akat ve Budak, 2002: 9); Sinırlı kaynaklarla örgüt amaçlarına etkili bir şekilde ulaşmak için başka insanlarla birlikte çalışmak (Özalp, 2004: 4); Örgütte amaçlara etkili ve verimli olarak ulaşılması adına yapılan yönetim fonksiyonu faaliyetlerinin tümü (Genç, 2007: 18); Hedeflere ulaşmak için eldeki kaynakları bir araya getirip yönetimin fonksiyonlarını uygulayan süreçtir (Öztürk, 2018a: 9; Topaloğlu ve Koç, 2005: 34).

Yönetimin kaynakları örgütten örgüte, kurumdan kuruma farklılık gösterse de genel olarak insan kaynağı, maddi imkanlar, norm kaynağı ve bilgi kaynağı olarak görmek mümkündür (Baransel, 1997: 17). Yönetimde asıl amaç örgütsel amaçlara ulaşmak için örgütsel faaliyetleri yerine getirmektir. Örgütün hedeflerine yönetimle ulaşılabilir. Çalışanların ve örgütün başarısı amaçlara ulaşmada etkinlik gösterilmesiyle ortaya konabilir (Topaloğlu ve Koç, 2017: 32; Genç, 2007: 18).

Yönetimin fonksiyonlarını Henry Fayol; Planlama, örgütleme, yönetme, koordinasyon ve denetleme (Aydın, 2006: 3; Eroğlu, 2011: 129) olarak belirtirken bunların tamamen doğal ve bilimsel yönetime katkıları anlamında kesin geçerli ilkeler olduğunu da belirtmektedir (Aydın, 2015: 125). Diğer yandan klasik yönetim ve örgüt teorisyenleri olan Luther Gullick ve Lyndall Urwick yönetim fonksiyonları için POSDCORB kısaltmasını yönetim bilimine kazandırmıştır. Bu kısaltmanın açılımı Planning, Organizing, Staffing, Directing, Coordinating, Reporting ve Budgeting İngilizce kelimeleri olup Türkçeleri sırasıyla Planlama, Örgütleme (organize etme), Personel İşlemleri, Yönlendirme-yönetme, Koordinasyon-eşgüdüm, Raporlama (denetleme, haberleşme) ve Bütçeleme şeklindedir (Öztürk, 2018b: 75; Sahin, 2017: 67; Aydın, 2015: 33; Aydın, 2011: 33; Aydın, 2006: 3). Personel işlemlerinden ilk etapta akla gelen eğitim ve işe almadır.

Personel alımında (Özalp ve diğerleri, 2004: 118-119) birincisi "personel biriminin sorumlu olması", ikincisi "ilgili birimin sorumlu olması" ve üçüncüsü de "hem personel biriminin hem de ilgili birimin sorumlu olması" olmak üzere üç farklı uygulama vardır. Birincisinde ilgili birimin beklentisini karşılayacak bir eleman alınamaması gündeme gelebilecek iken ikincisinde ilgili birim personel işlemleriyle uğraşırken kendi işini aksatabilecektir. Üçüncüsü ise ilk ikisinin eksikliklerini giderecektir, bir birime personel lazım $\mathrm{m}$, ihtiyaç var ise ne tür niteliklere sahip personele ihtiyaç vardır bunları en iyi ilgili birim bilir. Bunların seçimde sağlanıp sağlanmadığını da ilgili birim daha doğru olarak takip edebilir. Bunun yanında personel alma yoğun olarak yer alacak olan personel birimi, personel ihtiyacının olupolmadığı, var ise aranacak niteliklerin neler olduğunun belirlenmesinde ve aranana niteliklere sahip olunupolunmadığının tespiti anlamında seçim aşamasında ilgili birimden faydalanmalıdır.

Asıl olarak liyakat ve kayırma olmak üzere iki tür personel temin sistemi vardır. Liyakat (Şahin, 2017: 207); İşe eleman almada işin tanımına, gereklerine uygun niteliklere sahip olma kriterinin geçerli olmasıdır. Liyakat sisteminde işe alma, yer değiştirmesi, yükseltilmesi, maaş miktarı ve emeklilik vb tüm özlük işlemlerinde işin gereklerine uygun nitelikler yani önceden tanımlanan nitelikler çalışanların kişiliklerinden bağımsız olarak ele alınır. Kayırma sistemi; Örgütler rasyonel olarak kurulmalı ve öyle işletilmelidir, bu bağlamda örgüt kurulduktan sonra yine rasyonel olarak alt birimleri oluşturulduktan sonra bu birimler ve bu birimlerde çalışan personelin ne iş yapacağı nesnel olarak ortaya konmalıdır. Amaca ulaşmak için ihtiyaç duyulan alt birimler ve personel ihtiyacı ortaya konduktan sonra işe personel alımına sıra gelmektedir. Nesnellik ve rasyonellik gereği personel alımında işin gereklerine göre uygun, çalışacak elemanın bulunması esas olmalıdır. İşin gerekleri dışındaki sebeplerle personel alınırsa ya da personel alımında işin gereklerinin dışındaki sebepler dikkate alınarak personel alımı yapılırsa buna kayırma denmektedir. Siyasi iktidarların iktidara geldiğinde yaptıkları kadrolaşma, sözlü yapılan sınavlarda genel olarak yapıldığına inanılan torpil ya da personel almada hemşericilik, din-mezhep ayrımı, cinsiyet ya da bazı sülaleler için yapılan ayrımlar hep kayırma örnekleridir. En dikkat çekeni özel işletmeler için cinsiyet ayrımı ve kamu için siyaset olsa da burada saydığımız ayrımların hepsini her iki yönetimde de görmek mümkündür.

İşe alırken belli eğitim şartlarını koyup o şartları taşıyanlardan, ilgili eğitimi tamamlamış olanlardan eleman seçilebileceği gibi gerekli eğitimi vermek için meslek eğitim okulları kurarak oraya öğrenci alınıp gerekli formasyonun oralarda verilmesi de sağlanabilir. Gizlilik ve güvenlik gerekçeli durumlar gibi özellik arz eden kollarda ilgili 
okullar açıp elemanı yetiştirmek daha yaygın ve doğrudur. Ayrıca mesleğe alımdan sonra da gelişmeleri aktarmak ve gerekli güncelleme ve paylaşımları yapabilmek adına hizmet içi eğitimler de önem arz etmektedir.

\section{Türk Polis Teşkilatında İşe Alma Ve Eğitim}

\subsection{Türk Polis Teșkilatında İșe Alma}

Devlet Memurları Kanunu-DMK'nda Emniyet Hizmetleri Sınıfı deyince, üstten aşağıya emniyet müdürleri ile emniyet müdürü ünvanını kazanmış memurlar, emniyet amiri, başkomiser, komiser, komiser muavini, polis ve bekçi akla gelmektedir (DMK m.36). "Geçici ve sözleşmeli personeller hakkında kanunda özel hükümler düzenlenmiştir. Anayasa Mahkemesi üye ve yedek üyeleri ile raportörleri; ... ile Emniyet personeli özel kanunlarındaki hükümlere tabidirler." (DMK. m.1). Emniyet Teşkilatında polis memuru ve amir olmak üzere iki esaslı atanma söz konudur.

Polis Meslek Yüksekokullarındaki öğrenimlerini başarı ile tamamlayanlar, Emniyette aday polis memuru olurlar (Polis Yüksek Öğretim Kanunu-PYÖK m.10). Polis Akademisi'nde fakülteden öğrenimlerini, bu kanunla belirlenen sürede bitiremeyenler istekleri halinde, Bakanlıkça çıkarılan yönetmelikteki esaslara göre polis kadrolarına atanacaklardır (PYÖK m.16). Polis memuru olmak için diğer bir okul ise, ilgili kurumların görüşleri alındıktan sonra İçişleri Bakanlığının teklif etmesi sonrasında Bakanlar Kurulunca açılacak olan polis meslek eğitim merkezleridir. $\mathrm{Bu}$ merkezlerden başarı ile mezun olanlar, Emniyete aday polis memuru olurlar. (Emniyet Teşkilat Kanunu-ETK ek m.24).

Teşkilatta amir olabilmek için ise Polis Amirleri Eğitim Merkezi-PAEM'ndeki ilk derece amirlik eğitimi başarı ile bitirmek gerekir. Emniyette amir sınıfinda yer alabilmek için PAEM'in öğrenci kaynağı şunlardır; a) Emniyette en az iki yıl çalışmış, kırkbeş yaşını doldurmamış lisans mezunu polis, başpolis, kıdemli başpolis rütbesindeki memurlar. b) Emniyet çalışanı olmayan lisans mezunları ile Yükseköğretim Kurulu tarafından lisans mezunu kabul edilenler. c) İkili anlaşmalarda belirtildiği şekliyle yabancı uyruklular (Polis Akademisi Başkanlı̆̆ı Polis Amirleri Eğitimi Merkezi Giriş Ve Eğitim-Öğretim YönetmeliğiPAEMY m.5). İhtiyaç görüldüğünde a bendindeki özellikleri taşıyanlara yapılacak yazılı-sözlü sınavda başarılı olup, Polis Akademisindeki ilk derece amirlik eğitiminde başarılı olanlar Komiser Yardımcısı olurlar. Konuya dair diğer hususlar yönetmelikte belirlenir (ETK m.50). Girişteki Sınav aşamaları ise şu şekildedir: (1) PAEM'e giriş sınavında fiziki yeterlilik ve mülakat sınavları bulunmaktadır. (2) Emniyet mensubu adaylar için ayrıca bu sınavlardan önce yazılı test sınavı uygulanır. (PAEMY m.14). Bu öğrencilerin komiser yardımcısı olabilmeleri için öğrenimlerini başarı ile bitirmeleri ve ilgili yönetmelikte belirtilen sınavda başarılı olmaları şarttır (PAEMY m.42).

Merkezdeki intihap encümeni şe şekilde tertip olur: Emniyet Genel Müdürünün görevlendireceği bir yardımcısının başkanlığında daire başkanlarıyla hukuk işleri ve personel işlerine bakan şube müdüründen oluşur. $\mathrm{Bu}$ komisyonun kararları genel müdürün tasvibi ve Bakanlığın onaylamasıyla tamamlanır (ETK m.65). Vilayetlerdeki intihap encümeni ise, emniyet müdürü ile yardımcıları ya da bunların vekilleri başkanlığında şube müdürleri ya da vekillerinden oluşur. $\mathrm{Bu}$ komisyonun görevi mesleğe başvuranların evrakları üzerinden kanuna uygun vasıflara sahip olup-olmadıklarını araştırmaktır (ETK m.67).

İntihap ve tayin usulleri: Meslek derecesi dokuz, on ve on bir olan memurlar Merkezdeki İntihap Komisyon kararı ve Genel Müdürün inhası ve Bakanın tasvibiyle, meslek derecesi on iki olan memurlar, Emniyet Genel Müdürlüğünün ya da illerdeki emniyet müdürlerinin intihabı ve Emniyet Genel Müdürlüğünün inhası ve Bakanın onayıla atanırlar (ETK m.43). Emniyet Hizmetlerinde işe alma deyince aklımıza 9. Meslek derecesindeki Komiser Yardımcılığı ve 12. Meslek derecesindeki polis memurluğuna alma gelmektedir.

Devlet Memurları Kanunu'nda Memuriyete Girişte hem genel hem de özel şartlar bulunmaktadır. Devlet memurluğuna alınacaklarda aşağıdaki genel ve özel şartlar aranır. Genel şartlar: 1. Kişi Türk Vatandaşı olacak, 2. Yasal yaş şartlarına uygun olacak, 3. Yasayla gösterilen öğrenim şartına haiz olacak, 4. Kamu haklarında mahrumiyet olmayacak, 5. Yasada gösterilen süreler bitse dahi; kasten işlenen suçlarda bir yıl veya daha fazla hapis cezası veya affa uğramış olsa bile aynı yasada sayılan suçlardan mahkûmiyet almamış olmak. 6. Askerlikle işi bulunmamak, o çağa gelmemiş olmak ya da gelmiş ise askerlik hizmetini yapmış, erteletmiş ya da yedek sınıfa geçmiş durumda olmak, 7. Akıl sağlığı görevine engel olmamak. 8. Güvenlik soruşturmasının yapılmış olmasıdır. B) Özel şartlar: 1. Hizmet göreceği sinıfa uygun eğitim-öğretimini tamamlamak, 2. Özel kanunlarda kurumlarca aranan diğer şartlara sahip olmak (DMK m. 48). Yaş hususunda genel kaide 18 yaşını tamamlamış olmaktır, bunun yanında meslek-sanat okulu mezunlarında 15 yaşını doldurmuş olma ve bunun yanında Türk Medeni Kanunu'na göre kazai rüşt kararı almış olmak gerekir. (DMK m.40). Eğitim açısından genel kaide ortaokulu bitirmiş olmak, onlardan istekli yoksa ilkokulu bitirmiş olmaktır. Bazen bir sınıfta belli görevler için, mevzuatla işin gereğine uygun üst okul mezuniyeti, belli alan mezuniyeti, meslekle ilgili bir program mecburiyeti ya da yabancı dil şartları getirilebilir (DMK m.41)

Tablo 1. Türk Polis Teşkilatındaki Rütbeler- Meslek Dereceleri

\begin{tabular}{ll}
\hline Rütbe & Meslek Derecesi \\
\hline Sınıf Üstü Emniyet Müdürü & Derece Üstü \\
\hline$\ldots \ldots \ldots$ & $\ldots \ldots \ldots \ldots \ldots$ \\
\hline Komiser Yrd. & 9 \\
\hline Kıdemli Başpolis Memuru & 10 \\
\hline Başpolis Memuru & 11 \\
\hline Polis Memuru & 12 \\
\hline
\end{tabular}

\subsection{Türk Polis Teşkilatında Eğitim}

Polis Akademisi-Fakülte: Emniyetin gerek duyacağı memur ve amir personel ihtiyacını gidermek için lisans, lisans öncesi, ve üstü eğitim-öğretim yaptırmak, bilimsel araştırma ve yayın yapacak bilimsel özerkliği bulunan, içinde meslek 
yüksekokulları ile fakülte ve enstitü ihtiva eden Polis Akademisi oluşturulmuştur. Akademinin görevleri; a) Emniyete amir-yönetici yetiştirmek, b) Lisans düzeyinde eğitim-öğretim almış olan personele lisansüstü eğitim yaptırmak, c) Yüksekokullar ve merkezlerde polis memuru yetiştirmek, d) Emniyete gerekli olan eğitim ihtiyacının karşılanmasına çalışmak (PYÖK m.3). Adaylarda aranacak şartlar yönetmelikle belirlenmektedir (Polis akademisi başkanlığı güvenlik bilimleri fakültesi giriş ve eğitimöğretim yönetmeliği). Güvenlik Bilimleri Fakültesine dair diğer usuller yönetmelikle detaylandırılmaktadır.

Polis Akademisi- Polis Meslek Yüksekokulları: Bu yüksekokullar Polis Akademisine bağlı ve ön lisans seviyesinde olup mesleki eğitim-öğretim yapmaktadır. $\mathrm{Bu}$ okullara Öğrenci Seçme ve Yerleştirme Merkezince yapılan Öğrenci Seçme Sınavında başarılı olmuş lise veya dengi okul mezunlarından özel yetenek sınavın geçenler girebilir. Burada verilen öğrenimi başarı ile bitirenler Emniyette aday polis memuru olurlar (PYÖK m.10). Bu okullara başvuran adaylarda aranan nitelikler, giriş sınav ve usulleri ve diğer ayrıntılar ilgili yönetmelikte detaylandırılmaktadır Polis Meslek Yüksekokulları Giriş Yönetmeliği. Diğer yandan eğitim-öğretim esasları, devam mecburiyeti, çıkma çıkarılma vb. konular da başka bir yönetmelikte detaylandırılmaktadır (Polis Meslek Yüksekokulları EğitimÖğretim Yönetmeliği).

Polis Meslek Eğitim Merkezleri: Emniyetteki polis memuru ihtiyacı için, ilgili kurumların görüşü alınmak suretiyle İçişleri Bakanlığınca yapılacak öneri üzerine Bakanlar Kurulunca polis meslek eğitim merkezleri kurulabilir. Lisans mezunu olup Kamu Personeli Seçme Sınavına girmiş ve burada belirlenmiş olan taban puanı geçenlerden sınav yılının sonu itibarıyla otuz yaşını bitirmemiş olan adaylardan mevzuattaki şartları taşıyıp bu sınavlarda başarılı olanlar bu merkezlere girerler. Belirlenmiş olan kontenjanın \%20'sini geçmeyecek şekilde Bakanlık tarafından belirlenmiş kadar önlisans mezunları da bu merkezlere alınabilmektedir. Ayrıca özel harekat birimleri için, yirmisekiz yaşını bitirmemiş, lise mezunlarında Kamu Personel Seçme Sınavı şartı aranmadan, fiziki yeterlilik-mülakat sınavlarıyla bu merkezlere aday alınabilmektedir. Buradaki eğitimde başarılı olanlar, Emniyette aday polis memuru olurlar. Bunlar ilk altı yıl boyunca diğer kurumlara nakil olamazlar. Polis meslek eğitim merkezlerine dair diğer hususlar İçişleri Bakanlığınca hazırlanan yönetmelikte düzenlenmiştir (ETK ek m.24).

Kurumların memurlarını hizmet içinde yetiştirme esasları Devlet Memurları Kanunu'nda belirtilmiştir (DMK m.214218) ayrıca Emniyet teşkilatı için de branş kurslarına bakmak uygun olacaktır. Emniyette branşlı personel olmak için o branşın kursu görülüp başarılı olmuş olmak gereklidir. $\mathrm{Bu}$ kurslarda başarılı olanlar sertifikayla belgelendirilir (EHSBY m.7).

\section{4. İnterpol'de İşe Alma Ve Eğitim}

İnterpol'de resmi dil Arapça, İngilizce, Fransızca ve İspanyolcadır. Bu kurumda 100 farklı devletten 800 personel İnterpol merkezde, Bölge Büroları ile irtibat bürolarında görevlendirilmiştir. Bu personelin üçte biri İnterpol'e üye 192 üye ülkenin kolluk birimlerince görevlendirilmişlerdir; diğerleri de organizasyonca sözleşmeyle işe alınmış olan uluslararası görevlilerdir. İnterpol doğru temsil edilebilmek adına üye ülkelerin hepsinden başvurulara açıktır. İnterpol işe alacakları için bir takım genel şartlar koymuştur, bunlar (İnterpol How-to-apply?): Üye ülkelerin vatandaşı olmak; 18 ve daha büyük yaşta olmak; İs ilanındaki görev şartlarını taşımak; İstenen ve ilgili olan bir diploma ya da eğitime sahip olmak; İstenen alanda tecrübeli olmak; İngilizceyi mükemmel derecede bilmek ve iyi derecede Fransız bilmek; avantaj olarak örgütün çalışma dillerini az da olsa bilmek. İnterpol'de Üye ülkelerden görevlendirilecekler_İnterpol'e üye devletler tarafindan görevlendirilen yetkililer için istihdam koşuları) ve Sözleşmeli Çalışacaklar için (İnterpol'de sözleșmeli çalıșanlar için istihdam koșuları) farklı farklı koşullar konmuştur. Maaşlar bile çalışılan merkez ve pozisyona göredir.

İnterpol'de "polis eğitimi” kilit role sahiptir. İnterpol ona üye olan ülke polislerinin kapasitesini geliştirmekte ve onları eğitmektedir. Her yıl binlerce katılımcıyla operasyonel eğitim oturumları, seminerler-sempozyumlar, çalıştaytoplantı yapmaktadır (İnterpol uzmanlık, Eğitim ve Kapasite Geliştirme Faaliyetleri; Fact Sheet: 14). İnterpol'deki Eğitim Kalite Güvence sistemi eğitim programlarındaki dağılımda etkinliğe katkı yapmaktadır. Ulusal Merkez Büroları İnterpol'le ulusal polis birimleri arasındaki bağlantıyı sağlarken İnterpol bölgesel Büroları da eğitim faaliyetleri için son derece iyi donanıma sahiptir. Diğer yandan İnterpol Küresel Öğrenme Merkezi olarak çevireceğimiz The INTERPOL Global Learning Centre-IGLC, yetkililerin erişimine açı olan online öğrenme portalıdır. Bu programa 7 gün 24 saat I24/7 ağıyla web sitesi üzerinden ulaşılabilmektedir (Fact Sheet: 15). İnterpol'ün çok fazla eğitim programları vardır, bunlar: Ulusal Merkez Büroları ve kolluk ajansları için Kapasite geliştirme Programları (İnterpol Eğitim Faaliyetleri), Ulusal Merkez Bürolarına dair İnterpol Polis Geliştirme Programı (INTERPOL Police Development Programme for NCBs-IPD/NCBs), I-24/7 Eğitici Sertifika kursu, Uzun süreli Programlar (Fact Sheet: 14), İnterpol Mobil Polis Eğitim Programı (Interpol Mobile Police Training Programme-IMPTP), İhtisas Gerektiren Suç Sahaları Eğitimi, Geniş Kapsamlı Kurslar: Amerikalılara Organize Suçlara dair Program, Güneydoğu Asya'ya Göçmen Kaçakçılığ1-Yasadışı Göçü Önlemeye dair Program, Uluslararası Tehdit Değerlendirme ve İstihbarata dair Çalıştay, Afrika Boynuzuna ve Asya'ya Terörizmle Mücadele Programları, BM Güvenlik Konseyi yaptırımları ve Uygulanması Semineri, İnterpol Bildirimlerini Geliştirme Tamamlayıcı Eğitimi, Polis Eğitim Şefleri Sempozyumu ve İnterpol Liderlik Değişimi Eğitim Programıdır (Fact Sheet: 15).

\section{Europol'de İşe Alma Ve Eğitim}

Europol personeli genel polis, sınır polisi, gümrükler ve güvenlik servislerini içeren değişik türdeki kolluk ajanslarından gelmektedirler. Bu çok ajanslı yaklaşım bilgi boşluklarını kapatmaya ve suçluların hareket edebilecekleri boşlukları en aza indirmeye yardımcı olmaktadır (Europol Hakkımızda). Europol 1000'den fazla personeli, 200 Europol irtibat görevlisi, 100 civarında suç analistiyle her yıl 40000'den fazla uluslararası araştırmayı desteklemektedir (Europol Hakkında). Europol'ü Kuran Konsey Karar1EKKK'ndaki Düzenlemeler (Europol'ü Kuran 6 Nisan 2009 tarihli Konsey Kararı, m.39): Konsey'in 259/68 numaralı düzenlemesinde ( $\mathrm{AB}$ RG L56) ortaya konan Avrupa Toplulukları yetkililerinin Personel Düzenlemeleri ve 
Avrupa Toplulukları diğer memurlarının İstihdam Koşulları ve personel düzenlemelerine uygulanması amaciyla Avrupa Toplulukları kurumları tarafından ortaklaşa benimsenen kurallar Europol personeline de uygulanır. Personel istihdamına dair yetkiler Başkan ve kendi personeliyle ilgili olarak Europol tarafindan kullanılır. Europol personeli, geçici personel ve/veya sözleşmeli personelden oluşur. Yönetim Kurulu kuruluş planında sağlanan hangi geçici görevlerin yalnızca üye devletlerin yetkili otoritelerinden işe alınan personel tarafından doldurulabileceğine karar verir. $\mathrm{Bu}$ tür görevleri doldurmak için işe alınan personel İstihdam Koşullarının 2(a) maddesi altında geçici ajan olur ve bunlara yalnızca bir defaya mahsus belirli bir süre için yenilenebilir sabit süreli sözleşmeler verilebilir. Üye devletler Europol'e ulusal uzmanlar görevlendirebilir.

Europol İstihdam Uygunluk Kriterleri (Europol Recruitment Guidelines): Adaylar Europol'de bir pozisyona başvurması için aşağıdaki minimum-Genel Gereklilikleri karşılamalıdır: AB üyesi ülkelerden birinin vatandaşı olmalı ve vatandaş olarak tüm haklardan yararlanıyor olmalıdır. Askeri hizmetler ilgili olarak hukuk tarafindan ondan beklenen tüm yükümlülükleri yerine getirmiş olmalıdır. Fiziksel olarak pozisyonla bağlantılı görevleri yerine getirmeye uygun olmak; $\mathrm{Bu}$ nedenle herhangi bir istihdam teklifi, görevi almadan önce Europol'ün tıbbi hizmet sağlayıcısı tarafindan yapılan bir sağlık muayenesini tamamlaması şartı vardır. $A B$ dillerinden ${ }^{1}$ birini tam olarak ve $\mathrm{AB}$ dillerinden başka birini de tatmin edici şekilde bilmelidir. Bütün adayların Europol'ün iç haberleşme ana dili olan İngilizce bilgisine hakim olmaları gereklidir. $\mathrm{Bu}$ şart Seçim Komitesi tarafından, adayın sunduğu sertifika ve diplomalar temelinde kontrol edilir ve gerekirse seçim prosedürü ${ }^{2}$ sırasında ileri değerlendirme yapılır. Nitelikler, verilen bir pozisyonun eğitim gerekleri Europol'ce belirlenir ve ilgili uygulama şartlarının yanı sıra Görevlilerin Personel Yönetmeliği ve AB Diğer Çalışanlarının İstihdam Koşulları temelinde iş duyurusunda ortaya konmaktadır. Hizmetin gerektirmesi durumlarında eşit seviyede bir profesyonel eğitim seviyesi, iş ilanında ortaya konan şartlara uygun olarak özel profiller kabul edilebilmektedir. Profesyonel Eğitim aşağıdaki temellerde değerlendirilebilir:

Tablo 2. Europol AD5/AD6 Geçici Görevli Postları

\begin{tabular}{lc}
\hline $\begin{array}{l}\text { Profesyonel Eğitim } \\
\text { Süresi }\end{array}$ & $\begin{array}{c}\text { Eşitlik için gerekli olan ek } \\
\text { profesyonel tecrübe }\end{array}$ \\
\hline 6 aydan 1 yıla kadar & 3 yıl \\
\hline 1 yıldan 2 yıla kadar & 2 yıl \\
\hline 2 yıldan fazla & 1 yıl \\
\hline
\end{tabular}

Kaynak:https://www.europol.europa.eu/sites/default/files/p

ublications/1europol_

recruitment_guidelines.pdf, (10.08.2014).

1 AB resmi dilleri: Bulgarca, Hırvatça, Çekçe, Danimarkaca, Hollandaca, İngilizce, Estonyaca, Fince, Fransizca, İrlandaca, Almanca, Yunanca, Macarca, İtalyanca, Letonyaca, Litvanyaca, Maltaca, Polonyaca, Portekizce, Romanyaca, Slovakca, Slovenyaca, İspanyaca ve İsveçce'dir.
Tablo 3. Europol AD7/AD8 Geçici Görevli Postları

\begin{tabular}{lc}
\hline Profesyonel eğitim süresi & $\begin{array}{c}\text { Eşitlik için } \\
\text { gerekli olan } \\
\text { ek profesyonel } \\
\text { tecrübe }\end{array}$ \\
\hline 6 aydan fazla ve 1 yıla kadar & 4 yıl \\
\hline 1 yıldan fazla ve 2 yıla kadar & 3 y1l \\
\hline 2 yıldan fazla ve 3 yıla kadar & 2 yıl \\
\hline 3 yıldan fazla & 1 yll
\end{tabular}

Kaynak:https://www.europol.europa.eu/sites/default/files/p ublications/1europol_recruitment_guidelines.pdf , (10.08.2014).

Hizmetin faydası için gerekli olması halinde, sözleşmeyi yapan makam değişik kriterler koyabilir. Bazı postlar adayların belli süreli bir üniversite derecesi sunmasını gerektirir ve sadece $A B$ makamlarınca düzenlenen diplomalar ve ilgili $\mathrm{AB}$ üye devleti organınca eşitliği tanınan diplomalar kabul edilir. Sözleşme MakamıEuropol konusunda başkandır- biri Europol İnsan Kaynaklarından, biri ilgili servisten ve biri de Personel Komitesince görevlendirilen olmak üzere toplam üç üyeden oluşan bir Seçme Komitesi kurar. Mülakat ve yazılı Test/ Pratik Test: Genel olarak seçim prosedürü şunlardan oluşur: -Yazılı test (genellikle 2.5-4 saat, profile bağlı olarak). Pratik Testler (genellikle 30 dakika-4 saat, profile bağlı olarak). - Yeterliliğe dayalı mülakat (genellikle 30 dakika-1 saat). Europol tarafından organize edilen bir seçme prosedüründe yer alan adaylarca yapılan mesken ve seyahatle ilgili harcamalar geri ödenmektedir.

Europol'le iş sözleşmeli personeli, üye devletler, 3. Ülkeler ve organizasyonlardan irtibat görevlilerini, görevlendirilen ulusal uzmanları, eğitimcileri ve anlaşmalı tarafları içeren Europol Personel sayıs1, Aralık 2012: Europol İrtibat Görevlileri (Europol Liaison Officers-ELOs). 3. Ülke ve organizasyonlardan Europol İrtibat Görevlileri (ELOs) dahil.

Tablo 4. Europol İrtibat Görevlileri (ELOs)

\begin{tabular}{llllll}
\hline Y1l & 2001 & 2005 & 2010 & 2015 & 2017 \\
\hline Personel & 73 & 93 & 129 & 205 & 220 \\
Sayıs1 & & & & & \\
\hline
\end{tabular}

Kaynak:https://www.europol.europa.eu/content/page/staffstatistics-159, (10.08.2014).

Europol'de 2014 yılında 36'dan fazla değişik ülkeden yaklaşık 800 personel, 145 Europol İrtibat Görevlisi (ELOs) ve 100 civarında suç analisti bulunmakta (Europol about-us) olup \%34 bayan ve \% 66 erkek personeldir (2003'deki ortalama değerler- Europol Our People) aynı Europol 2017

2 Dil seviyelerine dair referans Genel Avrupa Çerçeve Çalışması çeşitli Avrupa dil seviyelerini tarif ederek bir öz değerlendirme şablonu sunar, $\mathrm{Bu}$ rehberin ek $\mathrm{B}$ 'de detaylar görülebilir. 
y1lında 1000'den fazla personeli, 200 Europol irtibat görevlisi, 100 civarında suç analistiyle her y1l 40000'den fazla uluslararası araştırmaya destekler duruma gelmiştir (Europol About Europol). 2017'deki toplam personel say1s1 1203'e ulaşmıştır (Europol statistics-data). Cinsiyet Dengesi Projesinin gelişmesi ve uygulanması, Europol'ün performansında pozitif bir etki yapacak olan daha çeşitli ve dengeli bir işgücüne sahip olmanın onaylanmasına dayalıdır. 2017'deki verilerde(Europol statistics-data); Europol personelinin \% 32.46's1 bayan iken \% 67.54'ü erkektir. Aşağıdaki Millet Tabanlı Europol Personeli Şemasına göre Hollanda 100 kişi ile birinci sırada iken Luxemburg 1 personelle sonuncu sirada yer almaktadir.

\section{Teksas Kamu Güvenliği Dairesi’nde İșe Alma ve Eğitim}

Personel Politikaları Devlet Yasasında şu şekilde düzenlenmiştir: (a) Müdür veya Müdürün tayin ettikleri ajans içi kariyer basamakları programı geliştirir. Bu program tüm giriş seviyesi dışındaki pozisyonların kurum içi görevlendirmelerin herhangi bir genel atamayla eşzamanlılığını gerektirir. (b) Müdür veya müdürün tayin ettiği, personel işlemlerinin ırk, renk, engellilik, cinsiyet, din, yaş veya milliyet orijinle bağlantılı olmadan yapılan personel işlemleri kapsamında bir eşit iş fırsatı programının uygulanmasını sağlamak için yazılı bir politika belgesi hazırlar ve sürdürür.

Texas'ta 75.138 adet Kolluk memuru (Peace Officers) atanmış durumdadır (Texas.gov). Texas Kamu Güvenliği Dairesi yalnızca online başvuruları kabul etmektedir. Texas DPS'de çalışmaya aday olanlar en az 17 yaşında olmalıdırlar, bazı pozisyonlar başkaca şartlar da gerektirebilir. Texas DPS'de çalışmak için Amerikan vatandaşlığını ispat etmek bir gerekliliktir ve doğum ya da vatandaşlık belgesi bu şartı karşılamaktadır. Ceza geçmişi kayıtları kontrollerini de içeren geçmiş soruşturması her potansiyel çalışan için yapılır ve suç ve kesin kötü davranış mahkumiyetleri hemen reddedilme sebebidir. Aynı resmi internet sitesinde hangi pozisyonlara aday aranıyor, ne kadar maaş alacak, çalışma türü ve son başvuru tarihleri de yayınlanmaktadır (txdps/default.cfm).

Bazı yarg1 çevrelerinde yerel polis adaylarının, diğerlerindeki yaklaşık 800'le karşılaştırınca 1500 saat civarındaki ortalama eğitimi tamamlamaları gerekmektedir. Ortalama olarak eyalet yasalarınca, eğitim saatlerinin yaklaşık dörtte üçü (3/4) süresi için bir ajans gereksinimi bulunmaktadır. Genel olarak dairelerin ancak \% 3'ü bir eğitim akademisine sahiptir (Osce Country_Profile_Section). Kolluk eğitimi (DPS police_training/overview.htm) açısından Texas Kamu Güvenliği Dairesi eyaletteki baş kolluk ajansıdır. Kolluk uygulamalarında karşılaşılan birçok zorluğu yenmek için daire dünya-sınıf eğitim programı uygulamaktadır. Kolluk Eğitimi acemileri, muhafızları, ajanları ve Texas eyaletindeki diğer kolluk memurlarını eğitir. Kolluk eğitimi programı fiziksel ve zihinsel olarak zorlu bir 20 haftalık sıkı işe alma eğitimi uygulamaktadır. Tüm Texas kolluk memurları her iki yılda bir en az 40 saatlik devamlı eğitimi tamamlamalıdırlar. Ek Eğitim, Eğitim ve Araştırma Programları ve Hizmetleri (DPS police_training/overview.htm): Çalışan Gelişimi (Employee Development-ED) kendi yetkili memurları gibi DPS'in yetkili olmayan memurları için de sınıflar açmakla görevlidir. Hangi derecedeki memurun ne kadar hangi alanlarda (memursa, amirse gibi ayrı ayrı) devamlı eğitim alması gerektiğini Texas Meslekler Yasası ve Eğitim Yasası düzenliyor, burada asgari almaları gereken eğitim ve süreleri ile ilgili komisyonun koyduğu kurallar da bulunmaktadır (Texas agency-chief-administrators).

\section{Almanya Bundeskriminalamt'ta İşe Alma ve Ĕgitim}

Almanya'da polislerin işe alınması daha ziyade eyalet polis birimleri tarafindan organize edilmekte ve temel eğitim bu eyaletlere bağlı polis okullarında verilmektedir. Bazı eyaletlerde, yetenekli memurların daha fazla eğitim ve terfi için seçilmesinde değerlendirme merkezleri kullanılmakta ama genel olarak ilk amir veya yüksek rütbeli görevlilerin değerlendirmeleri yeterli sayılmaktadır. Polisliğe almada yaş, boy ve kilo sınırı, vücut kütle oranı, IQ testleri, fizik kondisyon ve sağlık şartları (sağlık, genel, fiziki durum ve psikolojik şartlar) aranmaktadır, üst yaş sınırı genelde 26 olmaktadır. Mesela İngiltere'de polis olmak için yaş şartı: kuvvete bağlı olarak değişik sınırlar olabilmekle birlikte 18.5-55'tir (Policing in the UK: A Brief Guide: 5). Eyaletler arasındaki polis birimlerinde birbirine geçişler genelde çok zordur ve çok ender olarak karşılaşılmaktadır (Akar ve diğerleri, 2005: 22).

Münster'deki Alman Polis Üniversitesi’nde Alman Polis Üniversitesi Hukuku kapsamında yüksek lisans ve doktora yaptırılmaktadır. Üst düzey Polis Eğitim Akademisi (Polizei-Fuehrungsakademie-PFA) 2006'da Alman Polis Üniversitesi'ne (DeutscheHochschule der Polizei) dönüştürülmüştür (Osce Country_Profile_Section). Üniversiteye öğrenci seçimi, Almanya Polis Üniversitesi mevzuatına uygun olarak, Almanya Polis Üniversitesinin yakın bağlantısı ile Alman Federasyonu ve Federal devletlerin yargı çevresi kapsamında öğrenci seçimleri yapilmaktadir.

Almanya Polis Üniversitesi'nin görevleri özetle; 1 . eyalet ya da federal polis organizasyonlarındaki üniformalı ve suç polis hizmetlerindeki üst düzey pozisyon adaylarını eğitmek. 2. Federasyon ve Eyaletlerdeki üst düzey polisler için devam eğitimleri-iç hizmet eğitimi vermek. 3. Araştırma yapmak. 4. Dış İlişkiler. Üniversite, Avrupa Birliği polislerinin çalışma ziyaretlerinde federasyon ve eyaletler için Almanya Merkez Ofisidir (Osce Country_Profile_Section).

\section{Sonuç ve Öneriler}

Görüldüğü gibi her polis organizasyonunda genel ve özel şartlar bulunmaktadır. Bunlar vatandaşlık, yaş, sağlık, kısıtlı olmama ve adli sicil soruşturması sonucu uygulanan kısıtlılık, fiziksel ve yeteneksel gereklilikler, askerlik durumu şartı, işin gerekleri dışında ayrım yapılmaması ve yetkili otoritece görevlendirilme/ seçilme şartı olarak görülmektedir. Ayrıca bu organizasyonlarda seçilirken aranan bazı eğitim şartlarının yanında belli şartları taşıyanların resmi ajanslara alınarak gerekli eğitimin verilmesi ve hizmete alımdan sonra ortaya çıkan gereksinimler ve gelişmelerle kendini belirginleştiren eğitim ihtiyacının karşılanması şeklinde eğitim verilmekte ve aranmaktadir.

Ülkelerin polis organizasyonlarından uluslararası polis organizasyonlarının işe alma ve eğitim anlamında bazı 
farklılıkları vardır, bunlardan bazıları: a. işe almada genel olarak, uluslararası organizasyonların polislik anlamında zaten belli bir profesyonelliğe sahip olanları çalıştırmasının yanında ülke organizasyonlarının ihtiyacı olan profesyonel çalışanları kendisinin yetiştirmesi, b) Uluslararası organizasyonlar ulusal organizasyonlardan farklı olarak organizasyonun resmi dillerini bilen ya da kendisini oluşturan ülkelerin dillerini bilen personele yani personelin kullanabildiği dil unsuruna özel önem vermesi, c) Uluslararası organizasyonların eğitimleri daha ziyade kendi sistemlerinin tanıtımı ve kullanımı ile bağlı alt ofislerin eğitimine odaklanırken ulusal polis kurumlarının polislik mesleğinin temel gereksinimlerine sahip elemanlar yetiştirmeye odaklanmasıdır. Benzerlikler olarak baktığımızda: Genel ve özel şartların birbirine çok yakın olduğu ve hepsinde de hizmetin gerektirdiği özel şartların da olabileceği kabul edilmektedir. Eğitim olarak da birbirine yakın durumları görmek mümkün, aynı zamanda hizmette çalışan personel için de hizmet içi eğitim bağlamında her organizasyonun plan ve çalışmaları olduğu görülmektedir.

Hangisinin uyguladığı program daha iyidir konusu ayrıca araştırılmalıdır. Çünkü bu konu farklı bakış açıları, öncelikler açısından geniş bir değerlendirme ve çalışma gerektirecektir. Ancak eğitime ve işe alma ve devam eden süreçler açısından liyakat ve ussallığın özellikle her daim akılda tutulması gerektiğini belirtmek faydalı olacaktır.

\section{Kaynakça}

Akar, E., Özer, A. \& Demirci, B. (2005). Federal Almanya Polis Teşkilatı, http://www.pa.edu.tr/APP_DOCUMENTS/D478B2AD3813-4555-9629-

6332F8CF8D33/cms_statik/_dergi/2005/2/69-100.pdf, (01.06.2014).

Akat, İ., Budak, G. \& Budak G. (2002). İşletme Yönetimi, İzmir: Barış Yayınları.

Aydın, A. H. (2006). Kamu Yönetimi ve Polis, Ankara: Gazi Yayınlar1.

Aydın, A. H. (2011). Yönetim Bilimi, 4.B, Ankara: Seçkin Yayınları.

Aydın, A. H. (2015). Yönetim Bilimi, 6.B, Ankara: Seçkin Yayınları.

Baransel, A. (1997). Çağdaş Yönetim Düşüncesinin Evrimi, İstanbul: Venüs Yayınları.

Devlet Memurları Kanunu. http://www.mevzuat.gov.tr/MevzuatMetin/1.5.657.pdf (12.11.2017).

\section{DPS} administrators

http://www.tcole.texas.gov/content/agency-chiefadministrators, (05.07.2014/19.11.2017).

DPS police_training/overview. http://www.dps.texas.gov/trainingacademy/police_traini ng/overview.htm, (19.11.2017).

Emniyet Teşkilat Kanunu. http://www.mevzuat.gov.tr/MevzuatMetin/1.3.3201.pdf et: 05.05.2018
Eroğlu, E. (2011). İletişimci Liderlik, Konya: Literatürk Yayınlar1

Europol about Europol. https://www.europol.europa.eu/about-europol (19.11.2017).

Europol about us https://www.europol.europa.eu/content/page/about-us, (10.08.2014).

Europol Our People. https://www.europol.europa.eu/content/page/ourpeople-19, (10.08.2014).

Europol Recruitment Guidelines (Europol İstihdam Rehberi).

https://www.europol.europa.eu/sites/default/files/public ations $/ 1$ europol_recruitment_guidelines.pdf, (10.08.2014).

Europol staff-statistics. https://www.europol.europa.eu/content/page/staffstatistics-159, (10.08.2014).

Europol statistics-data. https://www.europol.europa.eu/about-europol/statisticsdata $(05.05 .2018)$

Europol'ü Kuran 6 Nisan 2009 tarihli Konsey Kararı. (2009/371/JHA), AB RG, 15/5/2009. https://www.europol.europa.eu/sites/default/files/counci 1_decision.pdf, (10.08.2014-05.05.2018).

FACT SHEET, Capacity Building And Training, COM/FS/2013-09/GI-07,

http://www.interpol.int/INTERPOL-expertise/Trainingand-capacity-building/Training-activities, (14.09.2014), s.14.

Genç, N. (2007). Meslek Yüksekokulları için Yönetim ve Organizasyon, Ankara: Seçkin Yayınları.

Güney, S. (2000). Yönetim ve Organizasyon El Kitab1, Ankara: Nobel Yayınları.

İnan, Ö. ve diğerleri, (2004). Yönetim ve Organizasyon, Eskişehir: Anadolu Üniversitesi Yayınları.

İnterpol How-to-apply? http://www.interpol.int/Recruitment/Other-recruitmentpages/How-to-apply, (14.09.2014).

İnterpol'de sözleşmeli çalışanlar için istihdam koşuları. http://www.interpol.int/Recruitment/Other-recruitmentpages/Employment-conditions-for-contracted-officials, (08.02.2018).

İnterpol'de Uzmanlık, Eğitim Ve Kapasite Geliştirme Faaliyetleri. http://www.interpol.int/INTERPOLexpertise/Training-and-capacity-building, (18.11.2017).

İnterpol'e üye devletler tarafından görevlendirilen yetkililer için istihdam koşuları. http://www.interpol.int/Recruitment/Other-recruitmentpages/Employment-conditions-for-seconded-officials, (18.11.2017).

İşe Alma, Değerler ve Temel Yeterlilikler. http://www.interpol.int/Recruitment, (18.11.2017). 
Osce

Country_Profile_Section. http://polis.osce.org/countries/details?item_id=69\#Coun try_Profile_Section_325, (05.07.2014).

Özalp, İ. (2004). Yönetim Organizasyon, Eskişehir: Açık Öğretim Fakültesi Yayınları.

Öztürk, C. (2018a), Liderlik Kamu Yönetiminde Lider Yöneticiye Doğru, Nobel Yayınları, Ankara.

Öztürk, C. (2018b), "Yönetim Fonksiyonu Olarak Örgütlenme, Yöneltme ve Birlikte Değerlendirilmeleri”, Yönetim ve Siyaset Değerlendirmeleri, C. Öztürk, A. Nauşabayeva Hekimoğlu, A. N. Buyruk Akbaba, Nobel Yayınc1lik, Ankara, s.73-94.

Policing in the UK: A Brief Guide, Association of Chief Police Officers (ACPO), www.acpo.police.uk/documents/.../201210Policinginthe UKFinal.pdf, (01.06.2014).

Polis akademisi başkanlığı güvenlik bilimleri fakültesi giriş ve eğitim-öğretim yönetmeliği. http://www.mevzuat.gov.tr/Metin.Aspx?MevzuatKod=7 $.5 .12360 \&$ MevzuatIliski $=0 \&$ sourceXmlSearch $=$ polis, (20.11.2014).

Polis Akademisi Başkanlığı Güvenlik Bilimleri Fakültesi Giriş $\quad V e \quad$ Eğitim-Öğretim Yönetmeliği.http://www.mevzuat.gov.tr/Metin.Aspx?M evzuatKod=7.5.12360\&MevzuatIliski=0\&sourceXmlSe arch $=$ polis, (20.11.2014).

Polis Akademisi Başkanlığı Polis Amirleri Eğitimi Merkezi Giriş Ve Eğitim-Öğretim Yönetmeliği. http://www.resmigazete.gov.tr/eskiler/2015/07/2015071 6- 4.htm (12.11.2017)

Polis Meslek Yüksekokulları Eğitim-Öğretim Yönetmeliği. http://www.mevzuat.gov.tr/Metin.Aspx?MevzuatKod=7 $.5 .12361 \&$ MevzuatIliski=0\&sourceXmlSearch= polis, (18.11.2017).

Polis Meslek Yüksekokulları Giriş Yönetmeliği. http://www.mevzuat.gov.tr/Metin.Aspx?MevzuatKod=7 .5.12145\&MevzuatIliski=0\&sourceXmlSearch= polis, (18.11.2017).

Polis Yüksek Öğretim Kanunu http://www.mevzuat.gov.tr/MevzuatMetin/1.5.4652.pdf (12.11.2017)

Teksas.gov. http://www.tcole.texas.gov/, (05.07.2014).

Texas DPS. http://agency.governmentjobs.com/txdps/default.cfm, (05.07.2014).

Topaloğlu, M. \& Koç, H. (2005). Büro Yönetimi Kavramlar ve İlkeler, Ankara: Seçkin Yayınları.

Topaloğlu, M. \& Koç, H. (2017). Yönetim ve Organizasyon, 3B, Ankara: Seçkin Yayınları.

UNAMID bünyesinde görev yapan bir Alman polis komiseri ve bir BKA çalışanının doldurduğu 05.02.2014 tarihli veri toplama sayfaları.

Yusuf, Ş. (2017). Yönetim Bilimi ve Türk Kamu Yönetimi, 7.B, Bursa: Ekin Yayınları. 